\title{
Defining Cultural Tourism
}

\author{
Seyed Sina Mousavi ${ }^{1}$, Naciye Doratli ${ }^{2}$, Seyed Nima Mousavi $^{3}$ and Fereshte Moradiahari ${ }^{4}$
}

\begin{abstract}
Tourism has a vital role in development of different destinations all around the world. Accordingly, culture is assumed as one of the primary beneficiaries and is regarded as a key asset in tourism development by promoting both tangible (i.e. cultural attractions, like museums and heritage centers, natural assets like beach, sun and mountain) and intangible (i.e. promoting gastronomy cultural events and festivals and selling "atmosphere") elements. However, the diversity of known definitions and a complex relationship between culture and tourism underlines the problem of defining cultural tourism. For instance, considering culture as a component in every single aspect of human life, it is possible to assume that everything is cultural, therefore all tourism are somehow cultural tourism. However, this broad and holistic approach is not particularly useful in identifying those cultural values important in tourism and vice versa, or in other words, in defining cultural tourism. This paper analyzes the ever changing and indistinct definition of cultural tourism by reviewing the known approaches and perspectives adopted in defining this complex concept.
\end{abstract}

Keywords - Cultural Tourism, Culture, Identity, Tourism.

\section{INTRODUCTION}

It may appear relatively easy to distinguish the difference between the concepts of culture and tourism as their boundaries clearly separate their meanings, where the same goes for the concept of cultural tourism. For instance it is generally agreed upon that visiting a cultural center in a country famous for its cultural manifestations is regarded as cultural tourism whereas a visit to a beach is not. However, in recent years, the two notions of tourism and culture and the meanings attached to them have experienced significant change, to a point where their distinctions have become blurred; for MacCannell (1993) 'all tourism is a cultural experience' and Urry (1990) believes 'tourism is culture'. These assumptions made some scholars believe that cultural tourism is something new or it is a postmodern phenomenon. However by examining the definition of cultural tourism, it becomes clear that "what has changed is the extent of cultural tourism consumption, and the forms of culture being consumed by cultural tourists." (Richards, 1996)

Cultural tourism, arguably, is regarded as the original form of tourism considering its roots in the Grand Tour

\footnotetext{
${ }^{1}$ Eastern Mediterranean University, Faculty of Architecture, Department of Architecture, North Cyprus.

${ }^{2}$ Prof. Dr. Eastern Mediterranean University, Faculty of Architecture, Department of Architecture, North Cyprus.

${ }^{3}$ Eastern Mediterranean University, Faculty of Architecture, Department of Architecture, North Cyprus.

${ }^{4}$ Eastern Mediterranean University, Faculty of Architecture, Department of Architecture. North Cyprus.
}

originated in the $16^{\text {th }}$ century in Britain; (Hibbert, 1969, Feifer, 1985). However, trying to define this concept is more challenging as it may sound; this complex concept may have different meaning for different people. McKercher and Du Cros (2002) discuss 'the number of definitions for cultural tourism nearly matches the number of cultural tourists'. According to a study conducted by European Commission regarding habits of cultural consumption for Europeans in 2002, people tend to visit galleries and museums abroad as frequently as they do at their homes. (European Commission, 2002) Although this issue highlights an emerging concern for cultural activities, it also manifests a contradiction regarding the difference between cultural tourism and cultural visits taken place at home. (Richards, 2003) In general, cultural tourism may be explained as the very nature of travelling in order to understand and become familiar with way of life and history of a specific location accompanied by a range of cultural factors which can be presented in the context of tourism, these factors may include the food, entertainment, architecture, drink, hand crafted and manufactured products or every element representing characteristics of way of life in a particular destination. (McIntosh and Goeldner, 1990) In addition, several non-cultural and non-educational activities may provide opportunities for familiarizing tourist with each other in a destination. Furthermore, the ongoing debates regarding the effects of cultural tourism on societies and the culture itself introduce another issue where promoting this 'potential source of tourism growth' will actually contribute to communities in terms of cultural and environmental values or 'penetrate sensitive cultural environments' and eventually diminish the very identity of destinations. As Butler (1990) argues; "although cultural tourists are usually seen as 'good' tourists who travel in small numbers and do little damage, they can arguably act as the 'Trojan Horse' that opens up a region to the less acceptable effects of mass tourism."

Therefore, it is not easy to provide a definite framework which demonstrates the importance and significance of cultural tourism and tourists in general or for a particular destination. Accordingly, defining the problematic concept of cultural tourism brings about a number of issues. One the most important issue lies within defining the two consisting elements of cultural tourism; 'culture' and 'tourism', which both, in their own terms, are difficult to explain. Majority of the available definitions for cultural tourism 'agree that it consists of the consumption of culture by tourists', however Richards (1996) argues defining this concept from this perspective reveals a number of fundamental questions;

- What kinds of culture should be included within the scope of cultural tourism? 
- Does a visit to a museum turn an entire holiday into a cultural tourism experience?

- Are tourists who engage in cultural consumption actually culturally motivated?

This paper outlines the definition of cultural tourism and its significance along with the ever changing relationship between two broad concepts of culture and tourism. However, it is essential to mention that defining the concept of cultural tourism is nearly an impossible task. There is no generally agreed upon definition for cultural tourism anywhere and most literatures unanimously skip providing a solid description for this concept. However, by reviewing the most common approaches adopted in describing cultural tourism, it is possible to provide a 'general' explanation for this ever changing concept.

\section{Cultural TOURISM}

In order to clearly define the concept of cultural tourism it is first necessary to have a basic understanding of the two complex definitions of culture and tourism. However, it should be noted that recognizing the two concepts of culture and tourism separately is considered as a prerequisite for defining cultural tourism. The definition of cultural tourism itself is quite different and should not be assumed as a combination of the meanings of these two terms, culture and tourism.

\subsection{Tourism}

Comparing to the broad concept of culture, tourism is perhaps an easier term to deal with. The known definitions of tourism is divided into two categorizes; the 'conceptual' definition of tourism, dealing with the core meaning of tourism, and the 'technical' definition of tourism, focused on evaluating and measuring the value of tourism which is particularly variable in different countries. These two categorizes are briefly explained in Figure 1 below.

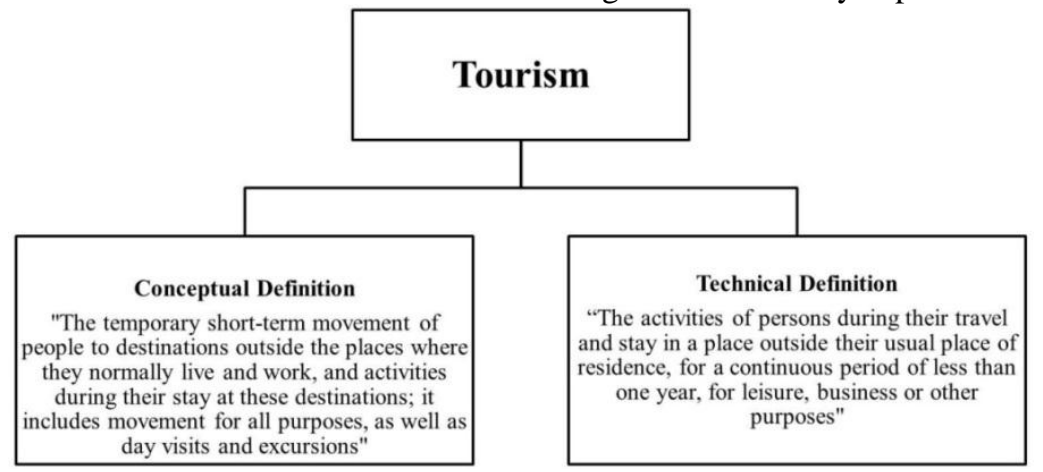

Fig. 1 Conceptual and technical definitions of tourism. Sources: WTO, 1993 and Holloway, 1985

\subsection{Culture}

Culture is a very complex concept; hundreds of definitions for it are in literatures. Generally, 'culture' is viewed as a "complex whole, which delivers a unifying concept for the extensively varied ways of life." "Trying to describe 'culture' in a single broadly acceptable definition therefore produces a level of generalization which renders the act of definition useless." (Richards, 1996) Two available uses of this concept in literature, culture as 'process' and culture as 'product', are described below.

\begin{tabular}{|c|c|}
\hline \multicolumn{2}{|c|}{ Culture } \\
\hline As 'Process' & As 'Product' \\
\hline $\begin{array}{l}\text { - Derived from anthropology and sociology which } \\
\text { regard culture mainly as codes of conduct } \\
\text { embedded in a specific social group. Culture } \\
\text { designates the social field of meaning } \\
\text { production, or the processes through which } \\
\text { people make sense of themselves and their lives. }\end{array}$ & $\begin{array}{l}\text { - Derives particularly from literary criticism. Culture } \\
\text { is regarded as the product of individual or group } \\
\text { activities to which certain meanings are attached, } \\
\text { Thus 'high' culture might be used by some to refer } \\
\text { to the products of famous artists, whereas 'low' } \\
\text { culture might refer to TV soap programs. }\end{array}$ \\
\hline
\end{tabular}

Fig. 2 Concept of culture in literature. Sources: Clarke, 1990 and Richards, 1996

In the field of tourism, these two distinctive approaches seem to slightly overlap and integrate. In other words, tourism, accompanied by other social mechanism, may act as a catalyst to transform culture as process into culture as product, thus isolating and detaching cultural products from their initial social context. As mentioned before, this issue poses a challenge in defining the creditability of cultural tourism in the first place.
Although understanding different definitions of culture and its role in society may easily reveal its relation to tourism, it would be unwise and needless to explain them in this article. Ashworth (1995) categorized three definitions of culture related to tourism shown in Figure 3 The first one and the most limited definition is aesthetic productivity. Regarded as 'Art Tourism', this is the simplest form of culture to be commodified for tourism, generally associated with art and artistic products and performance; i.e., theater, ballet, concert, 
festivals, museums and opera performances (Ashworth, 1995). The second definition of culture is mentioned as 'Heritage Tourism', most manifested in a mix of preserved buildings, conserved cityscapes and morphological patterns, as well as places associated with historical events and personalities. The last and the most general of the three definitions of culture mentioned by Ashworth is 'Place-specific Tourism', 'meaning that culture can be defined as the common set of values, attitudes and thus behavior of a social group'(Ashworth, 1995).

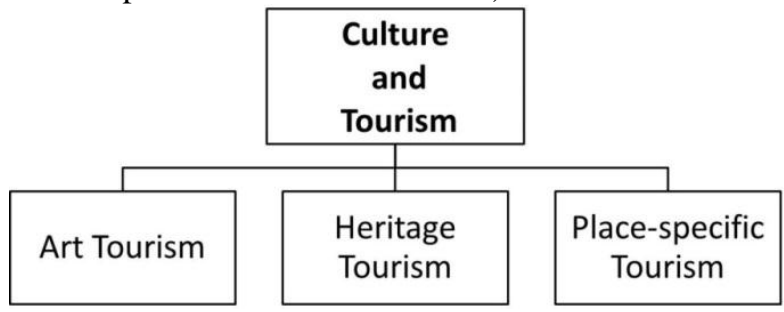

Fig. 3 Definitions of culture related to tourism. Source Ashworth, 1995

\subsection{Typology of Cultural Tourist}

Before discussing the definition and different approaches surrounding the concept of cultural tourism, it is necessary to briefly identify discrete types of cultural tourists. Stebbins
(1996) suggests that in general, cultural tourists can be divided into two main categorize of specialized and general where both types tend to avoid commercial ventures located within their area of interest.

\begin{tabular}{|l|l|}
\hline \multicolumn{1}{|c|}{ The 'general' cultural tourist } & The 'specialized' cultural tourist \\
\hline $\begin{array}{l}\text { Makes a hobby of visiting different } \\
\text { geographic sites. Over time, as general } \\
\text { cultural tourists increase their knowledge of } \\
\text { different cultures, they may become } \\
\begin{array}{l}\text { specialized cultural tourists who focus on } \\
\text { one or a small number of geographic sites or } \\
\text { cultural entities. }\end{array}\end{array}$ & $\begin{array}{l}\text { Repeatedly visits a particular city, region, or } \\
\text { country in search of a broad cultural } \\
\text { understanding of the place, or goes to } \\
\text { different cities, regions, or countries in } \\
\text { search of exemplars of, for instance, a kind } \\
\text { of art, history, festival, or museum. }\end{array}$ \\
\hline
\end{tabular}

Fig. 4 Categories of cultural tourists in general. Source Stebbins, 1996

However, Stebbins list for different cultural tourist is quite general and despite what its name suggests, is not specifically related to cultural tourism. A more detailed typology for cultural tourism by McKercher and Du Gros categorize cultural tourists in response to their depth of experience and also the importance of culture, as a motivator, in their travel. (Figure 5) The first three types of cultural tourists; the purposeful, the sightseeing and the serendipitous can, arguably, are considered as the primary cultural tourist due to their main motivator and experience for choosing a destination for the sake of cultural values. Comparing to the list provided by Stebbins, these three types of cultural tourist can be regarded as specialized and the other two; casual and incidental, are within the category of general cultural tourists.

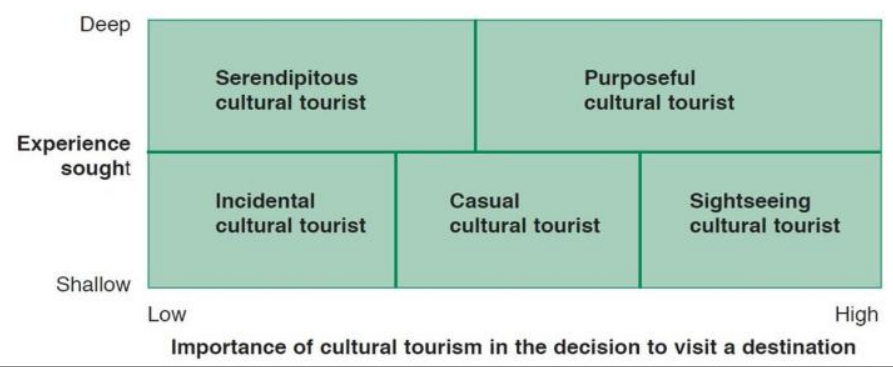

\footnotetext{
- The purposeful cultural tourist Cultural tourism is the primary motive for visiting a destination and the tourist has a very deep cultural experience;

- The sightseeing cultural tourist Cultural tourism is a primary reason for visiting a destination, but the experience is less deep; - The serendipitous cultural tourist A tourist who does not travel for cultural reasons, but who, after participating, ends up having a deep cultural tourism experience;

- The casual cultural tourist Cultural tourism is a weak motive for travel and the resulting experience is shallow;

- The incidental cultural tourist

This tourist does not travel for cultural reasons, but nonetheless participates in some activities and has shallow experiences.
}

Fig. 5 Typology of cultural tourist. Source: McKercher and Du Cros (2002) 


\subsection{Cultural Tourism in Context}

The main usage of the term cultural tourism involves the consumption of a wide range of cultural manifestations like heritage, art, folklore and etc. by tourists. Cultural tourism can be generally seen as a sociocultural relationship between people which is promoted, moderated and mediated by a range of various actors including, planners, politicians, researchers, marketing professionals, travel agencies and so on. Cultural tourism can be regarded as a meeting between social systems and cultures which will produce changes in both of them (Smith, 1992). As a social practice, cultural tourism reconstructs or constructs identities (e.g. nationalism, social identities, and transnationalism) and will eventually contribute to globalization and framing a globalized world. (Bauman, 1999).

Bonink (1992) identifies two approaches regarding the definition of cultural tourism; the 'sites and monuments' approach, focusing on explaining the type of attractions visited by cultural tourists, which mainly describes culture as a product (Richards, 1996). This quantitative approach simply assumes cultural tourism as a consumer of cultural attractions and proposes a relatively limited view of the motivations and activities of cultural tourists, thus restricting its analysis to specific attractions and sites. For instance, site and monument approach of cultural tourism, typically, consider the following attractions and sites as 'intangible' and 'tangible' expressions of culture which attracts cultural tourists. (ECTARC, 1989)
- Architecture (ruins, famous buildings, whole towns)

- Art, sculpture, crafts, galleries, festivals, events

- Music and dance (classical, folk, contemporary)

- Drama (theatre, films, dramatists)

- Language and literature study, tours, events

- Religious festivals, pilgrimages

- Complete (folk or primitive) cultures and sub-cultures

The second approach, called 'the conceptual approach', attempts to define cultural tourism in a more qualitative way through analyzing the practices, experiences and meanings of cultural tourist in contact with other places and cultures. As Richards (1996) describes; 'as with tourism in general, conceptual definitions of cultural tourism attempt to describe the motive and meanings attached to cultural tourism activity.' For example, McIntosh and Goeldner (1986) define 'cultural tourism' including 'all aspects of travel, whereby travelers become familiar with the heritage and history of others or their contemporary ways of life or thought". In other words, "the processes and products of other cultures are what cultural tourism offer to cultural tourists.

Furthermore, Pereiro, (2002) argues that from this standpoint, cultural tourism can be defined in a different way; 'as a process of commodification, a nostalgia for heritage and the past, a psychological experience, process of learning and curiosity, a modern form of pilgrimage, as an industry which represents cultural values and as a specific way of cultural consumption'.

- Archaeological sites and museums

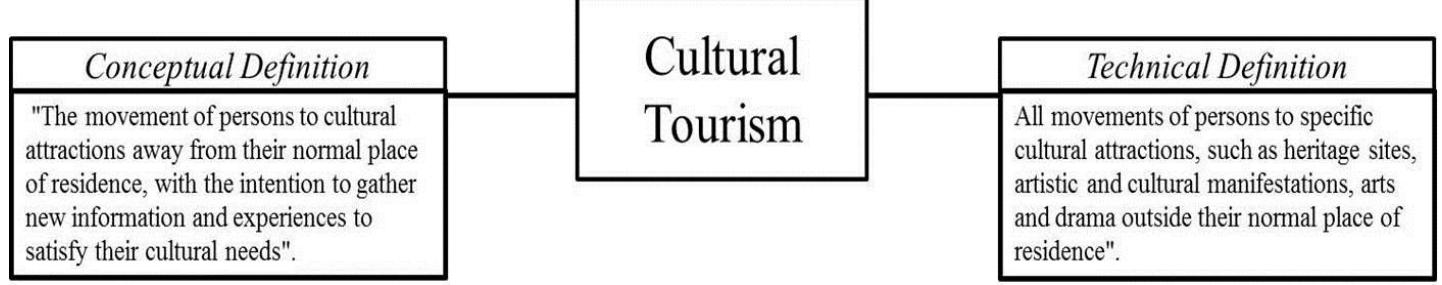

Fig. 6 Definitions of 'cultural tourism' Sources: Ashworth (1995), Richards (1996) and http://www.atlas-euro.org

Further study on the conceptual definition of cultural tourism suggests this approach stimulated a move away from culture as product to culture as process or "way of life" definitions of culture which is visible in the growing interest of tourists in experiencing lifestyle, customs and everyday life of people in different destinations. In other words, the previous preoccupation of tourism with natural resources and landscapes seems to be more involved in sensory and symbolic consumption of the ideas and images associated with particular destinations. (OECD, 2009) This expanding and diverse pattern of cultural consumption for tourists primarily dealing with intangible elements make defining the concept of culturally motivated and also cultural tourism even more difficult.

\subsection{The Importance of Identity}

One of the most important 'components' of cultural tourism and tourism in general is the issue of identity. Particularly in recent years, the struggle for creating and meditating the identity has become an inseparable feature of cultural tourism. In other words, identity is assumed as a primary value both for cultural tourists and their hosts; the hosts want to promote a unique identity for their communities to lure visitors thus bringing the associated benefits of tourism, on the other hand this unique 'local' identity will satisfy the thirst of cultural consumption and help distinguish the cultural tourist. According to Richards and Pereiro (2006) the factors responsible for emergence of identity as a key element in cultural tourism are;

- The need for regions to distinguish themselves

- The search for new forms of community

- The need to valorize culture

- The shift towards experiential tourism

- Postmodern/postcolonial reification of identity

Identity itself can be described as a "process of social construction of meanings that utilizes cultural attributes' which occurs in the context of power relations." (Richards. 2006) In order to clearly understand the emerging role of identity in cultural tourism, it is noteworthy to briefly describe three basic types of identity distinguished by Manuel Castells (2000). 


\begin{tabular}{|l|l|l|}
\hline 'Legitimated'Identity & 'Resistant' Identity & 'Projectual' Identity \\
\hline $\begin{array}{l}\text { Created by dominant } \\
\text { institutions to legitimate } \\
\text { their power over other } \\
\text { social actors. }\end{array}$ & $\begin{array}{l}\text { A claim by social actors in } \\
\text { low social positions who } \\
\text { are stigmatized by the } \\
\text { dominant groups. It is a } \\
\text { construction of alternative } \\
\text { social principles of } \\
\text { organization, it is more } \\
\text { communal and represents } \\
\text { a defensive identity } \\
\text { aganipulate their cultural } \\
\text { materials and construct a } \\
\text { new identity that redefines } \\
\text { their position in society } \\
\text { and transforms the social } \\
\text { structure }\end{array}$ \\
\hline \\
domination.
\end{tabular}

Fig. 7 Three basic types of identity. Source: Castells, (2000)

Cultural tourism can play an important role and contribute to all these three types of identity; for instance; promoting 'national monuments' thus supporting legitimate identity, creating 'alternative' cultural itineraries for resistant identity and of course promoting new images for communities for projectual identity. Therefore, it is obvious that cultural tourism can play a crucial role in construction and reconstruction of identity for the sake of tourism consumption. In other words, as a 'mechanism of cultural and social change', tourism has a significant influence on transformation of identity where in some situations cultural tourism may reinforce this identity, in other cases it may add new senses and meanings to peoples and spaces thus altering and transforming identity fundamentally. However, no matter how this process of 'commodification of culture' proceeds, the social costs of it cannot be ignored. (Santana, 1997)

Furthermore, another factor which reveals the close relationship between identity and cultural tourism is the current issue of globalization along with loosened social ties, decline in traditional family forms and structure and individualism. This emerging situation calls for a redefined 'symbolic constructions for communities' where cultural tourism can acts as an ideological stimulus in order to promote a new image and identity in response to the contemporary social relation thus modifying the borders and boundaries between different human groups both in local and global level.

\section{CONCLUSION}

Regardless of dramatic attention given to the concept of cultural tourism in recent years, the basic problem of defining it is not yet solved. The reason behind this issue is maybe cultural tourism is the offspring of culture; which is regarded as one of the 'most complicated words in the English language'. (Williams, 1983) This uncertainty and diversity in defining cultural tourism becomes even more problematic when a 'heterogeneous assortment of terms', like art tourism heritage tourism, ethnic tourism and so on, with interchangeable usage are being widely adopted and used both in policy statements and literatures without a solid framework clarifying their differentiation or similarities. (Richards, 1999) Nevertheless, there is nearly no doubt that culture is a crucial component of tourism 'product' and it may determine the competiveness and effectiveness of tourism destinations. Reviewing the conceptual definition of culture reveals that culture consists of both products ( like buildings, customs and arts ) and process (like way of life) associated with culture.
From this perspective however, cultural tourism is not merely associated with visiting monuments and sites, which is the traditional view of cultural tourism, it also includes consuming the way of life in different destinations. In other words, cultural tourism is not just about consuming cultural products of the past; it also deals with contemporary way of life and culture of people.

Accordingly, this view of cultural tourism, to some extent, moves in harmony with current issue of globalization and the inevitable process of commodification associated with it. It is believed that cultural tourism or tourism in general, plays an important role in diminishing local identity of communities considering the very nature of tourism development dictates that commodities should be presented to tourists in exchange of economic benefits. Furthermore, considering the contemporary pattern of cultural consumption among cultural tourists explained before, this commodification process associated with tourism development does not limit to physical products, but the elements of everyday life of locals as well. (Richards, 1999)

This issue poses a major challenge in discussing the significance of cultural tourism and its impacts on identity whereas to what extent this process of commodification should continue both for cultural tourist consuming these commodified products (to an extent where their identity is 'determined by consumption of others'?) and local people selling their identity, exhausting cultural resources and living a life expected from them by tourists.

\section{REFERENCES}

[1] Ashworth, G.J., Dietvorst A. G. (1995). Tourism and spatial transformations. CAB International, Wallingford, Oxon, UK.

[2] Bauman, Z. (1999): La globalización. Consecuencias humanas. Buenos Aires: FCE.

[3] Butler, R. (1990) Alternative Tourism: Pious hope or trojan Horse? Journal of Travel Research. https://doi.org/10.1177/004728759002800310

[4] Castells, M. (2000): La era de la información. Economía, Sociedad y Cultura. Vol. 2. El Poder de la Identidad. Madrid: Alianza Editorial.

[5] Clark, J. (1990) Pessimism Versus Populism: The Problematic Politics of Popular Culture. In: Butsch, R. (ed.) For Fun and Profit: The Transformation of Leisure into Consumption. Temple University Press, Philadelphia.

[6] ECTARC (1989) Contribution to the Drafting of a Charter for Cultural Tourism. European Centre for Traditional and Regional Cultures, Llangollen, Wales.

[7] European Commission (2002) Europeans and their holidays. EC, Brussels.

[8] Feifer, M. (1985) Tourism in History. From Imperial Rome to the Present. Stein and Day, New York. 
[9] Hibbert, C. (1969) The Grand Tour. Putnam, London.

[10] Holloway, J.C. (1985) The Business of Tourism. MacDonald and Evans, Plymouth.

[11] MacCannell, D. (1993) Empty Meeting Grounds; the Tourist Papers. Routledge, London.

[12] McIntosh R and Goeldner C (1990) Tourism: Principles, Practices, Philosophies (6th ed.), New York: John Wiley \& Sons, Inc.

[13] McKercher, B and Cros,H (2002) Cultural tourism: the partnership. between tourism and cultural heritage management. New York: Haworth Hospitality Press.

[14] OECD, Organization for Economic Co-Operation and Development. (2009) The Impact of Culture on Tourism. OECD publications. [available online] www.oecd.org/publishing/corrigenda.

[15] Pereiro, X. (2002): "Turismo Cultural: Leituras da Antropologia", in Actas do I Congresso Internacional de Turismo Cultural. Buenos Aires: Noticias de Antropología y Arqueología (NAYA)

[16] Richards, G (1996) Cultural Tourism in Europe, Wallingford, CAB International

[17] Richards, G. (1999) Culture, Cultural Tourism and Identity. Tilburg University, The Netherlands.

[18] Richards, G. (2001) The Development of Cultural Tourism in Europe. In Richards, G. (ed.) Cultural Attractions and European Tourism. Wallingford: CABI. https://doi.org/10.1079/9780851994406.0000

[19] Richards, G. (2001), Cultural Attractions and European Tourism, CABI, Wallingford. https://doi.org/10.1079/9780851994406.0000

[20] Richards, G. (2003) What is Cultural Tourism? In van Maaren, A. (ed) Erfgoed voor Toerisme. Nationaal Contact Monumenten.

[21] Richards, G. and Pereiro X. (2006) Cultural Tourism: Negotiating Identities. Universidade de Trás-Os-Montes e Alto Douro. ATLAS. Chaves, Portugal

[22] Santana, A. (1997): Antropologia y turismo. Barcelona: Ariel.

[23] Silberberg, T (1995) 'Cultural Tourism and Business Opportunities for Museums and Heritage Sites', Tourism Management v16 n5: 361-365

[24] Smith, V. (1992): Anfitriones e invitados. Antropología del Turismo. Madrid: Endymion.

[25] Stebbins, R A (1996) 'Cultural Tourism as Serious Leisure', Annals of Tourism Research v23 n4: 948-950

[26] Towner, J. (1985) The Grand Tour: a key phase in the history of tourism. Annals of Tourism Research. 12, 297-333 https://doi.org/10.1016/0160-7383(85)90002-7

[27] Urry, J. (1990) The Tourist Gaze: Leisure and Travel in Contemporary Societies. Sage, London.

[28] Williams, R. (1983) Keywords. Fontana, London.

[29] World Tourism Organization (1993) Recommendations on Tourism Statics. WTO, Madrid. 